\title{
Healthcare Professional's Perception of Pharmacist's Relationship and Counseling Skills in Saudi Arabia
}

\author{
Yousef Ahmed Alomi ${ }^{1, *}$ D, Sarah Abdullah Al-Hathlool², Maryam Ibrahim Almulhim², Amal Ali \\ Alashaq ${ }^{2}$, Yousef Aboshalaf ${ }^{3}$, Mytham Al-Ethan ${ }^{4}$ \\ ${ }^{1}$ The Past General Manager of General Administration of Pharmaceutical Care, The Past Head, National Clinical \\ pharmacy and pharmacy practice, The Past Head, Pharmacy R and D Administration, Ministry of Health, Riyadh, \\ SAUDI ARABIA. \\ ${ }^{2}$ Clinical Pharmacy Staff, Ministry of Health, Riyadh, SAUDI ARABIA. \\ ${ }^{3}$ Head of Pharmacy Services, King Fahad Hospital, Alhasa Medical Affairs, Ministry of Health, SAUDI ARABIA. \\ ${ }^{4}$ Assistant head of Pharmacy Services, King Fahad Hospital, Alhasa Medical Affairs, Ministry of Health, SAUDI \\ ARABIA.
}

\begin{abstract}
Purpose: To explore the healthcare provider's perception of pharmacist's relationship, communication, and counseling skills in Saudi Arabia. Methods: This is a 4-month crosssectional survey of the healthcare professional's perception of the pharmacist. The survey consisted of two parts: first part gathers demographic information and the second part contains 49 questions divided into four domains. (1) the first domain captures data regarding the healthcare provider's general perception about the pharmacist; (2) the second domain captures data regarding the healthcare professional's perception of pharmaceutical services; (3) the third domain was regarding the healthcare professional's perception of visiting ambulatory care; and (4) the fourth domain captures the data regarding the healthcare professional's perception of pharmacist's relationship and counseling skills. All healthcare professionals responded to the 5-point Likert response scale system. The survey was distributed through social media to more than 1000 healthcare professionals across the Kingdom of Saudi Arabia. Because the survey was in an electronic format, we were able to analyze and discuss the four domains with respect to the healthcare professional's perception of pharmacist's relationship and counseling skills through the Survey Monkey system. Results: A total of 170 healthcare providers responded to our survey. Of all the responders, 129 (75.9\%) were females and 41 (24.1\%) were males. Most of the healthcare providers were pharmacists ( $81(47.65 \%))$, others (33 (19.41\%)), nurses $(27(15.88 \%))$, and physicians $(23$ (13.53\%)). Most of the healthcare providers $(143(87.2 \%))$ spent less than 16 minutes waiting for the medication from the pharmacy. The average score of the healthcare professional's perception of the pharmacist's communication and relationship skills was around (3.41). The highest score with respect to the pharmacist's and patient's relationship was obtained for the following statements: "The pharmacist politely delivers the medication" (3.96) and "The pharmacist answers questions in an excellent manner" (3.67). The average score of healthcare professional's perceptions of pharmacists with medication counseling skills was around (3.42). Highest scores were obtained for the following statements: "All the medications received were packed" (4.28) and "The patient understands what the pharmacist was saying" (4.14). The highest score with respect to the patient's relationship with the drug information center was obtained for the statement: "The pharmacist answers patient's questions through drug information center of the hospital over 24/7" (3.44) and "Poisonous cases first contact the national drug information center or any other hospital drug information center any time through $\mathrm{MOH}$ hotline 937 service over $24 / 7$ " (3.37). Conclusion: The results of this survey revealed that healthcare professionals had an acceptable perception of the pharmacist with respect to communication and patient counseling skills. The healthcare professional's privacy, easy contact with the pharmacist, and drug-related problems information improve the pharmaceutical services offered to the healthcare professionals in Kingdom of Saudi Arabia.

Key words: Healthcare professional, Perception, Pharmacist, Relationship, Counseling skills, Ministry of Health, Saudi Arabia.
\end{abstract}

Received: 10-06-2018;

Accepted: 04-08-2018

*Correspondence to:

Dr. Yousef Ahmed Alomi Email: yalomi@gmail.com DOI: 10.5530/ijpcs.2018.7.4 Copyright: (c) the author(s),publisher and licensee International Journal of Pharmacology and Clinical Sciences. This is an open-access article distributed under the terms of the Creative Commons Attribution Non-Commercial License, which permits unrestricted non-commercial use, distribution, and reproduction in any medium, provided the original work is properly cited.

This is an open access article distributed under the terms of the Creative Commons AttributionNonCommercial-ShareAlike 4.0 License

Access this article online

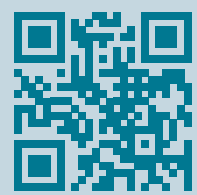

www.ijpcs.net 


\section{INTRODUCTION}

In general, hospitals have various medical professionals including physicians, pharmacists, nurses, nutritionists, social workers, and other healthcare professionals. Each of them has specific roles and responsibilities, and they all wish to provide best care to the patient. The physician sees the patient through the diagnosis; the pharmacist provides the best and appropriate drug for the patient to prevent his/her drug-related problems. The nurses take care of the patient and administer medications. Thus, every member of the team needs to have fundamental skills to provide the best care to the patient. Communication, relationship, and medication counseling skills are very important to all members of the healthcare team. Several studies investigated the patient's perception about the pharmacist's communication, relationship, and patient counseling skills. ${ }^{1-4}$ A previous study has reported the healthcare professionals' perception of the pharmacist in general which involves the pharmacist's communication and relationship skills. ${ }^{2}$ Most of the studies have explored the physician's perception alone, and to the best of our knowledge, there is no study that has included all healthcare professionals' perception of the pharmacist with respect to their communication or relationship skills and medication counseling skills in Saudi Arabia or Gulf and Middle East countries. Therefore, the primary objective of this study is to explore the healthcare provider's perception of the pharmacist with the emphasis on communication and relationship skills in the Kingdom of Saudi Arabia.

\section{METHODS}

This is a 4-month cross-sectional survey of healthcare professional's perception of a pharmacist. The survey consisted of two parts: the first part captured the demographic information and the second part has 49 questions that are divided into four domains. (1) the first domain is regarding the healthcare providers general perception of the pharmacist; (2) the second domain captures healthcare professionals' perception of pharmaceutical services; (3) the third domain is regarding the healthcare professional's perception of visiting ambulatory care; and (4) the fourth domain captures healthcare professional's perception regarding pharmacist's relationship and counseling skills. All healthcare professionals responded to the 5-point Likert response scale system. There were open- and closeended questions. The survey was distributed through social media, namely, WhatsApp to more than 1000 healthcare professionals across the Kingdom of Saudi Arabia. A reminder message was sent to the healthcare professional after 2 weeks and additional reminder messages were sent after 4 weeks. The survey was made available via an electronic format, and the necessary information about healthcare professional's perception regarding pharmacist's relationship and counseling skills were analyzed through Survey Monkey system.

\section{RESULTS}

A total of 170 healthcare professionals responded to the survey. Of them, 150 (93.8\%) was Saudi and 10 (6.25\%) was non-Saudi professionals. Of all the responders, $129(75.9 \%)$ were females and $41(24.1 \%)$ were males. Most of them (95.8\%) were in the age group of 18-44 years. In addition, 69 (41.6\%) professionals were located in Riyadh region, $36(21.7 \%)$ were located in East Province region, and $26(15.66 \%)$ were located in Alhasa region. The highest level of education of the responders was Bachelor's degree (126 (76.4\%)) followed by Diploma (16 (9.7\%)). Most of the healthcare providers were pharmacists $(81(47.65 \%))$, others (33 $(19.41 \%))$, nurses $(27(15.88 \%))$, and physicians (23 $(13.53 \%))$. During the past 12 months, majority of the patients visited the pharmacy more than 10 times 53 (31.36\%), whereas the others visited at least 5-9 times (40 (23.67\%)). Most healthcare professionals visited the pharmacy during the evening time $(79(47.31 \%))$ and during the morning time (54 (32.34\%)). Most of them (143 (87.2\%)) spent less than 16 minutes waiting for the medication from the pharmacy as explored in Table 1. The average score of the healthcare professional's perception of the pharmacist's communication and relationship skills was around 3.41. The highest score with respect to the pharmacist's and patient relationship skills was for the following statement: "The pharmacist politely delivers the medication" (3.96); "The pharmacist answers questions in an excellent way" (3.67); and "All pharmacists characterized with courtesy and respect" (3.45). The lowest score was obtained for the statement: "Communication with pharmacy by phone at any time" (2.73). The average score of healthcare professional's perceptions of pharmacists with medications counseling was 3.42. The highest score was obtained for the statement: "All the medications received were packed" (4.28) and "The patient understands what the pharmacist was saying" (4.14). Followed by the instruction labeled on each medication (4.05) and All introduction to medications written clearly (3.7). The lowest score was obtained for the statement "The place of pharmacy counseling 
Alomi, et al.: Healthcare professional's perception of counseling skills in Saudi Arabia

\begin{tabular}{|c|c|c|}
\hline & Response Count & Response Percent \\
\hline \multicolumn{3}{|l|}{ Sex } \\
\hline Female & 129 & $75.9 \%$ \\
\hline Male & 41 & $24.1 \%$ \\
\hline Answered question & 170 & \\
\hline Skipped question & 0 & \\
\hline \multicolumn{3}{|l|}{ Nationality } \\
\hline Saudi & 150 & $93.75 \%$ \\
\hline Non-Saudi & 10 & $6.25 \%$ \\
\hline Answered question & 160 & \\
\hline Skipped question & 10 & \\
\hline \multicolumn{3}{|l|}{ Age } \\
\hline$<18$ & 0 & $0.00 \%$ \\
\hline $18-29$ & 127 & $75.60 \%$ \\
\hline $30-44$ & 34 & $20.24 \%$ \\
\hline $45-59$ & 7 & $4.17 \%$ \\
\hline $60+$ & 0 & $0.00 \%$ \\
\hline Answered question & 168 & \\
\hline Skipped question & 2 & \\
\hline Type of visit & Response Count & Response Percent \\
\hline Physician & 23 & $13.53 \%$ \\
\hline Dentist & 4 & $2.35 \%$ \\
\hline Pharmacist & 81 & $47.65 \%$ \\
\hline Nurse & 27 & $15.88 \%$ \\
\hline Others & 33 & $19.41 \%$ \\
\hline Answered question & 170 & \\
\hline Skipped question & 0 & \\
\hline $\begin{array}{l}\text { In the last } 12 \text { months, the number of times } \\
\text { visited the pharmacy }\end{array}$ & Response Count & Response Percent \\
\hline None & 6 & $3.55 \%$ \\
\hline 1 time & 15 & $8.88 \%$ \\
\hline 2 & 21 & $12.43 \%$ \\
\hline 3 & 19 & $11.24 \%$ \\
\hline 4 & 15 & $8.88 \%$ \\
\hline 5 to 9 & 40 & $23.67 \%$ \\
\hline 10 or more times & 53 & $31.36 \%$ \\
\hline Answered question & 169 & \\
\hline Skipped question & 1 & \\
\hline Time of Visiting the Pharmacy & Response Count & Response Percent \\
\hline Morning & 54 & $32.34 \%$ \\
\hline Evening & 79 & $47.31 \%$ \\
\hline Night & 34 & $20.36 \%$ \\
\hline Answered question & 167 & \\
\hline Skipped question & 3 & \\
\hline The waiting time to get the medications & Response Count & Response Percent \\
\hline$<5$ & 70 & $42.68 \%$ \\
\hline $5-10$ & 53 & $32.32 \%$ \\
\hline
\end{tabular}


Alomi, et al.: Healthcare professional's perception of counseling skills in Saudi Arabia

\begin{tabular}{|c|c|c|}
\hline $11-15$ & 20 & $12.20 \%$ \\
\hline $16-20$ & 7 & $4.27 \%$ \\
\hline $21-25$ & 3 & $1.83 \%$ \\
\hline $26-30$ & 3 & $1.83 \%$ \\
\hline $31-35$ & 0 & $0.00 \%$ \\
\hline $36-40$ & 1 & $0.61 \%$ \\
\hline $41-45$ & 1 & $0.61 \%$ \\
\hline $46-50$ & 0 & $0.00 \%$ \\
\hline $51-55$ & 1 & $0.61 \%$ \\
\hline $56-60$ & 1 & $0.61 \%$ \\
\hline more than 60 years or equal & 4 & $2.44 \%$ \\
\hline Answered question & 164 & \\
\hline Skipped question & 6 & \\
\hline Qualifications of responders & Response Count & Response Percent \\
\hline Doctorate degree & 6 & $3.64 \%$ \\
\hline Master degree & 8 & $4.85 \%$ \\
\hline Bachelor Degree & 126 & $76.36 \%$ \\
\hline Diploma & 16 & $9.70 \%$ \\
\hline High school & 8 & $4.85 \%$ \\
\hline Intermediate School & 0 & $0.00 \%$ \\
\hline Primary School & 1 & $0.61 \%$ \\
\hline Not educated & 0 & $0.00 \%$ \\
\hline Answered question & 165 & \\
\hline Skipped question & 5 & \\
\hline
\end{tabular}

\begin{tabular}{|l|c|c|c|c|c|c|c|}
\hline \multicolumn{2}{|c|}{ Table 2: Healthcare provider's perception regarding pharmacist's communication and relationship skills. } \\
\hline Answer Options & $\begin{array}{c}\text { Strongly } \\
\text { agree }\end{array}$ & Agree & Neutral & Disagree & $\begin{array}{c}\text { Strongly } \\
\text { disagree }\end{array}$ & $\begin{array}{c}\text { Rating } \\
\text { Average }\end{array}$ & $\begin{array}{c}\text { Response } \\
\text { Count }\end{array}$ \\
\hline $\begin{array}{l}\text { 1. When you are receiving your prescription } \\
\text { medications, the pharmacist delivers your } \\
\text { medicines in a polite way }\end{array}$ & 40 & 84 & 35 & 4 & 1 & 3.96 & 164 \\
\hline $\begin{array}{l}\text { 2. Pharmacists have technical skills (thoroughness, } \\
\text { carefulness, competence) }\end{array}$ & 24 & 48 & 43 & 36 & 11 & 3.23 & 162 \\
\hline $\begin{array}{l}\text { 3. All pharmacists characterized with courtesy and } \\
\text { respect. }\end{array}$ & 32 & 48 & 52 & 24 & 7 & 3.45 & 163 \\
\hline $\begin{array}{l}\text { 4. The way the pharmacist answers my questions } \\
\text { excellent. }\end{array}$ & 32 & 65 & 53 & 9 & 5 & 3.67 & 164 \\
\hline $\begin{array}{l}\text { 5. Getting through to the pharmacy by phone } \\
\text { is comfortable and any times }\end{array}$ & 12 & 30 & 52 & 36 & 31 & 2.73 & 161 \\
\hline answered question & & & & & & & 165 \\
\hline skipped question & & & & & & 5 \\
\hline
\end{tabular}

respect my privacy" (2.61), "The pharmacist explains all the possible side effects" (2.9), and "The pharmacist provides you information about the proper storage of your medication" (2.92) (Tables 2 and 3 ). The highest score related to the patient's relationship with drug information centers was obtained for the statement: "The pharmacist answers patient question through drug information center hospital over 24/7” (3.44) and "poisonous cases first contact the national drug information center or any hospital drug information center any time through $\mathrm{MOH}$ hotline 937 over 24/7" (3.37) (Table 4).

\section{DISCUSSION}

The pharmacy strategic plan at Ministry of Health $(\mathrm{MOH})$ in Saudi Arabia consisted of five goals. The fourth goal of the plan discussed pharmacy, human 


\begin{tabular}{|l|c|c|c|c|c|c|c|}
\hline \multicolumn{2}{|c|}{ Table 3: Healthcare provider's perception regarding pharmacist's patient medication counseling skills. } \\
\hline Answer Options & $\begin{array}{c}\text { Strongly } \\
\text { agree }\end{array}$ & Agree & Neutral & Disagree & $\begin{array}{c}\text { Strongly } \\
\text { disagree }\end{array}$ & $\begin{array}{c}\text { Rating } \\
\text { Average }\end{array}$ & $\begin{array}{c}\text { Response } \\
\text { Count }\end{array}$ \\
\hline $\begin{array}{l}\text { 1. The place of pharmaceutical counseling } \\
\text { respects your privacy. }\end{array}$ & 14 & 26 & 42 & 44 & 37 & 2.61 & 163 \\
\hline 2. All medications you received packed. & 71 & 75 & 15 & 3 & 1 & 4.28 & 165 \\
\hline 3. Instructions labeled on each medication & 63 & 67 & 20 & 11 & 4 & 4.05 & 165 \\
\hline $\begin{array}{l}\text { 4. Instructions that contains: (patient's name, } \\
\text { medication's name, medication's strength and how } \\
\text { to use) written clearly. }\end{array}$ & 48 & 61 & 23 & 21 & 3.70 & 164 \\
\hline $\begin{array}{l}\text { 5. The pharmacist provides you written/ or printed } \\
\text { information about drug therapy and diseases. }\end{array}$ & 38 & 63 & 27 & 24 & 13 & 3.54 & 165 \\
\hline $\begin{array}{l}\text { 6. The pharmacist Explains to you how to know if } \\
\text { medications are working }\end{array}$ & 28 & 43 & 34 & 42 & 17 & 3.14 & 164 \\
\hline $\begin{array}{l}\text { 7. The pharmacist explains all the possible side } \\
\text { effects }\end{array}$ & 17 & 44 & 36 & 40 & 27 & 2.90 & 164 \\
\hline $\begin{array}{l}\text { 8. The pharmacist provides you information about } \\
\text { the proper storage of your medication. }\end{array}$ & 18 & 47 & 30 & 42 & 27 & 2.92 & 164 \\
\hline $\begin{array}{l}\text { 9. The pharmacist provides you with thorough } \\
\text { medication counseling and encourages you to ask } \\
\text { questions. }\end{array}$ & 17 & 44 & 44 & 30 & 28 & 2.95 & 163 \\
\hline 10. You understand what pharmacist saying & 50 & 92 & 14 & 4 & 2 & 4.14 & 162 \\
\hline answered question & & & & & & & 167 \\
\hline skipped question & & & & & 3 \\
\hline
\end{tabular}

Table 4: Healthcare provider's relationship with drug information centers.

\begin{tabular}{|c|c|c|c|c|c|c|c|}
\hline Answer Options & $\begin{array}{l}\text { Strongly } \\
\text { agree }\end{array}$ & Agree & Neutral & Disagree & $\begin{array}{l}\text { Strongly } \\
\text { disagree }\end{array}$ & $\begin{array}{l}\text { Rating } \\
\text { Average }\end{array}$ & $\begin{array}{l}\text { Response } \\
\text { Count }\end{array}$ \\
\hline $\begin{array}{l}\text { 1. Telephone numbers of hospital drug information } \\
\text { centers are available and easy to access }\end{array}$ & 16 & 29 & 54 & 51 & 15 & 2.88 & 165 \\
\hline $\begin{array}{l}\text { 2. The pharmacist answer patient question through } \\
\text { drug information center hospital over } 24 / 7\end{array}$ & 24 & 44 & 77 & 12 & 8 & 3.39 & 165 \\
\hline $\begin{array}{l}\text { 3. National drug information center provides } \\
\text { consultation services and answer questions } \\
\text { through } \mathrm{MOH} \text { hotline } 937 \text { over } 24 / 7\end{array}$ & 18 & 48 & 98 & 2 & 0 & 3.49 & 166 \\
\hline $\begin{array}{l}\text { 4. If there are any poisonous cases first contact } \\
\text { the national drug information center or any hospital } \\
\text { drug information center any time through } \mathrm{MOH} \\
\text { hotline } 937 \text { over } 24 / 7\end{array}$ & 24 & 47 & 75 & 15 & 3 & 3.45 & 164 \\
\hline answered question & & & & & & & 166 \\
\hline skipped question & & & & & & & 4 \\
\hline
\end{tabular}

resources, and satisfaction of medical culture. The pharmacist shared certain responsibilities with the physician in several programs to improve the services provided to the patient, such as stewardship, antimicrobial services, and pain management services. In addition to the anticoagulation program and $\mathrm{MOH}$ evidence base therapeutic guidelines. Despite the collaborations between the pharmacist and the healthcare professional, the perceptions of physicians toward pharmacist was missed. The authors tried in this study to explore the perception of healthcare providers of the pharmacist in communication and leadership. The results showed that healthcare professional's perception of the pharmacist with respect to his/her communication and relationship skills was adequate. The pharmacists showed proper communication skills with elements such as politely delivering the medicines, respecting the healthcare professionals, and being of them careful, which is a sign of good performance. Moreover, the pharmacist answers the healthcare providers questions. However, the weak point is that the healthcare providers are not available for communication with a pharmacist all the time. This may be because pharmacists will be busy with patients or in telephonic conversation. According to our results, the pharmacists answered the questions in an excellent manner as part of the patient education services, which was found to be lower than what has been reported by Oshima et al. This may be because in Oshima's study, pharmacists had good communication with healthcare providers than our site. ${ }^{5}$ The findings of healthcare professional's perception with patient 
medication education was acceptable. They received appropriate packages of the medications and the medications were labeled with appropriate instructions and the healthcare professionals could understand the pharmacist's advice. Despite these advantages, the place for patient privacy was the weakest point during patient counseling. In addition, education regarding drug-related problems to the healthcare professionals was other weakness points. This may be because the pharmacist is unfamiliar with them or the pharmacist has not had proper patient medication education program. Our results with respect to patient's perception was found to be higher than what has been reported by Al-Arifi and Merks et al. ${ }^{4,7}$ However, they were lower than what has been reported by Jose $e$ t al. and Schindel et al. This may be because of the pharmacist's prior experience in patient counselling services. ${ }^{4,6-8}$ The healthcare professionals showed high perception of $\mathrm{MOH}$ hotline with national drug information services and the network of drug information centers. They regularly answer the drug information and poisoning case. The hotline was established in 2014 to respond all patients or healthcare professionals related questions. The national drug information center and the network of drug information centers answer healthcare providers' drug information inquiries. A study was published regarding the analysis of drug information inquiries by healthcare providers and cost avoidance of preventing drug-related problems with healthcare professionals. ${ }^{9}$ However, this study explored the healthcare provider's perception of services that did not exist before; therefore, some findings of this study could not be compared with those published in previous investigations. Within proper health care professional's perception, the pharmacist should expand the pharmacy services and improve the relationships between the pharmacists and healthcare professionals in the Kingdom of Saudi Arabia.

\section{CONCLUSION}

The results of this study demonstrate that healthcare professionals had an acceptable perception of the pharmacist with respect to his/her communication and relationship skills and patient medications education. We need to focus on creating a private area and specific instruction about drug-related problems and complications is necessary to all healthcare providers in the Kingdom of Saudi Arabia.

\section{ACKNOWLEDGMENT}

None.

\section{CONFLICT OF INTEREST}

None.

\section{ABBREVIATIONS}

KSA: Kingdom of Saudi Arabia; MOH: Ministry of Health.

\section{ORCID ID}

Yousef Ahmed Alomi D https://orcid.org/0000-00031381-628X

\section{REFERENCES}

1. Worley MM. Testing a pharmacist-patient relationship quality model among older persons with diabetes. Res Soc Adm Pharm. 2006;2(1):1-21.

2. Oshima S, Senoo K, Negishi A, Akimoto H, Kutsuma N, Juni K, et al. Identification of the Discrepancies between Pharmacist and Patient Perception of the Pharmacist's Role as an Advisor on Drug Therapy Based on Social Science Theory. Biol Pharm Bull. 2016;39(39):313-22.

3. Carter SR, Moles R, White L, Chen TF. The impact of patients' perceptions of the listening skills of the pharmacist on their willingness to re-use Home Medicines Reviews: A structural equation model. Res Soc Adm Pharm. 2015;11(2):163-75.

4. Al-Arifi MN. Patients' perception, views and satisfaction with pharmacists' role as health care provider in a community pharmacy setting at Riyadh, Saudi Arabia. Saudi Pharm J. 2012;20(4):323-30.

5. Oshima S, Senoo K, Negishi A, Akimoto H, Kutsuma N, Juni K, et al. Identification of the Discrepancies between Pharmacist and Patient Perception of the Pharmacist's Role as an Advisor on Drug Therapy Based on Social Science Theory. Biol Pharm Bull. 2016;39(39):313-22.

6. Jose J, Al Shukili MN, Jimmy B. Public's perception and satisfaction on the roles and services provided by pharmacists - a Cross-sectional survey in Sultanate of Oman. Saudi Pharm J. 2015;23(6):635-41.

7. Merks P, Świeczkowski D, Jaguszewski MJ. Patients' perception of pharmaceutical services available in a community pharmacy among patients living in a rural area of the United Kingdom. Pharm Pract (Granada). 2016;14(3)

8. Schindel TJ, Yuksel N, Breault R, Daniels J, Varnhagen S, Hughes CA. Perceptions of pharmacists' roles in the era of expanding scopes of practice. Res Soc Adm Pharm. 2017;13(1):148-61.

9. Alomi YA, Almudaiheem HY, Alarnous T, Alshurei S, Alsharafa A, Alzahrani T, et al. Cost-Efficiency of National Drug Information Center Through Ministry of Health Hotline Calling Services (937) in Saudi Arabia: Application of American Model. Value Health. 2015;18(7):A735.

Cite this article as: Alomi YA, Al-Hathlool SA, Almulhim MI, Alashaq AA, Aboshalaf Y, Al-Ethan M. Healthcare Professional's Perception of Pharmacist's Relationship and Counseling Skills in Saudi Arabia. Int J Pharmacol. Clin. Sci. 2018;7(4):11-6. 